\title{
Improved Buchwald-Hartwig Amination by the Use of Lipids and Lipid Impurities
}

\author{
Ashot Gevorgyan,* Kathrin H. Hopmann, and Annette Bayer
}

Cite This: https://doi.org/10.1021/acs.organomet.1c00517

Read Online

\begin{abstract}
The development of green Buchwald-Hartwig aminations has long been considered challenging, due to the high sensitivity of the reaction to the environment. Here we show that food-grade and waste vegetable oils, triglycerides originating from animals, and natural waxes can serve as excellent green solvents for Buchwald-Hartwig amination. We further demonstrate that amphiphiles and trace ingredients present in triglycerides as additives have a decisive effect on the yields of Buchwald-Hartwig aminations.
\end{abstract}

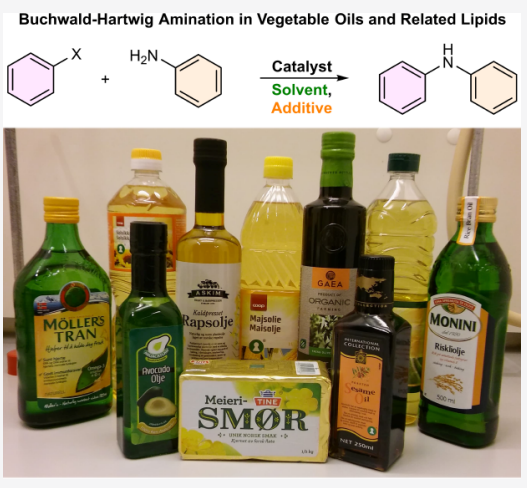

\section{INTRODUCTION}

$\mathrm{C}-\mathrm{N}$ bonds are omnipresent in natural products and pharmaceuticals. According to a recent study, over $62 \%$ of bioactive molecules described in the medicinal chemistry literature possess a $\mathrm{C}-\mathrm{N}$ bond in the form of primary, secondary, or tertiary amines. ${ }^{1}$ While different variations of $\mathrm{C}\left(\mathrm{sp}^{3}\right)-\mathrm{N}$ bond forming reactions were invented over a century ago, $\mathrm{C}\left(\mathrm{sp}^{2}\right)-\mathrm{N}$ bond construction was quite challenging until the late 1990s but was effectively resolved by the invention of the Buchwald-Hartwig amination. ${ }^{2,3}$ The significance of the Buchwald-Hartwig amination was demonstrated by Brown et al. in their study on past and present synthetic methodologies used in medicinal chemistry, where the Buchwald-Hartwig amination was found to be among the top 20 most frequently used reactions. ${ }^{4}$ Similar surveys by Schneider et al. $^{5}$ on the methodologies used in pharmaceutical patents and Gillet et al. ${ }^{6}$ on an analysis of Electronic Lab Notebooks of a major pharmaceutical company further evidenced the importance of Buchwald-Hartwig amination for the pharmaceutical industry.

Among Pd-catalyzed cross-coupling reactions, the Buchwald-Hartwig amination was invented and established most recently (Figure 1A). One reason for the slow development may be that the Buchwald-Hartwig amination is very sensitive to the reaction conditions, including the Pd precatalyst, the ligand, the additives, and the solvent. In fact, the reproducibility of previously developed methodologies can vary drastically depending on the origin and quality of the reagents used, the Pd source, and solvents. ${ }^{2 a, 7}$ This was well illustrated by Richardson et al., who performed a model BuchwaldHartwig amination in the presence of a range of chemicals containing different functional groups to establish how these would interfere. $^{7 \mathrm{c}}$ The results of over 3000 experiments indicated that the majority of functional additives have a negative influence on the outcome of Buchwald-Hartwig aminations, whereas some completely terminate the reaction. For functional additives inhibiting the reaction, the authors had to conduct a full set of optimizations in order to find new productive conditions.

In a recent study, we showed that vegetable oils and related lipids are excellent, sustainable, and safe solvents for $\mathrm{Pd}$ catalyzed $\mathrm{C}-\mathrm{C}$ bond forming cross-coupling reactions. ${ }^{8 a}$ In the present study, we developed a protocol for the more challenging Buchwald-Hartwig amination in vegetable oils and related lipids (Figure 1B; for the description of used lipids see Figures S1-S19 in the Supporting Information). ${ }^{9}$ We also found that trace ingredients, originating from and present in triglycerides, are valuable additives to improve the yields of Buchwald-Hartwig amination performed in a wide range of solvents, including lipids, traditional and green solvents.

\section{RESULTS AND DISCUSSION}

First, we were interested in the development of conditions suitable for Buchwald-Hartwig amination in vegetable oils (Table 1; for a detailed description of the setup of experiments

Special Issue: Sustainable Organometallic Chemistry

Received: September 13, 2021 
(A) Previous work: C-N bond forming reactions in non-renewable solvents<smiles>[X]c1ccccc1</smiles>

(B) Present study: C-N bond forming reactions in vegetable oils<smiles>[X]c1ccccc1</smiles><smiles>c1ccc(Nc2ccccc2)cc1</smiles>

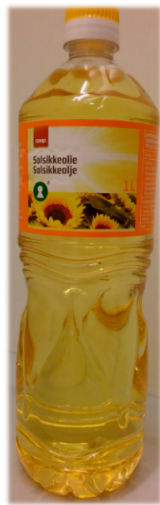

Figure 1. Previous work on Buchwald-Hartwig amination in nonrenewable solvents $(A)^{2,3}$ and present research on the use of lipids for $\mathrm{C}-\mathrm{N}$ bond forming reactions (B) (picture taken by A.G.).

Table 1. Optimization of Buchwald-Hartwig Amination in Rapeseed Oil from Askim



${ }^{a}$ Yields were determined by ${ }^{1} \mathrm{H}$ NMR using 1,3,5-trimethoxybenzene as an internal standard. ${ }^{b}$ Isolated yield.

see Figures S20-S29 in the Supporting Information). The reaction was initially examined in rapeseed oil from the brand Askim, using reference substrates 4-methoxyaniline (1a) and 3,5-bis(trifluoromethyl)bromobenzene (2a) (for complete optimization tables see Tables $\mathrm{S} 1-\mathrm{S} 5$ in the Supporting Information). A number of sterically constrained strong $\sigma$ donor phosphine ligands were combined with $\mathrm{Pd}_{2}(\mathrm{dba})_{3}$ as the catalyst precursor. Among the tested Buchwald ligands, the results were unsatisfactory only for JohnPhos (31\%, Table 1, entry 8$)$. The yields of the amination product 3 a were good for tBuXPhos (77\%) and DavePhos (84\%) (entries 1 and 4), while XPhos, SPhos, BrettPhos, and RuPhos resulted in quantitative yields (entries 2 and 5-7). Moreover, the chelating ligand XantPhos gave excellent yields (98\%, entry 11 ), whereas other bulky phosphines $\left(\mathrm{Ad}_{2} \mathrm{BuPHI}, t \mathrm{Bu}_{3} \mathrm{PHBF}_{4}\right.$, QPhos) and $\mathrm{NHC}$ ligands ( $\mathrm{IPrHCl}$ ) were not effective (entries $12-15)$. It is worth noting that in the case of $t \mathrm{BuXPhos}$ it was possible to improve the yield from $77 \%$ to quantitative by changing the source of Pd to $t$ BuXPhos Pd G3 (entry 10).
Similarly, in the case of XPhos it was possible to significantly reduce the catalyst loading by switching to XPhos Pd G3 (entry 9).

Encouraged by the good performance of various catalytic systems in rapeseed oil from Askim, we examined a range of lipids as solvents for Buchwald-Hartwig amination with XPhos Pd G3/XPhos as the catalytic system (Chart 1). Initially, we compared reactions performed in rapeseed oils from six different producers (orange columns). In our previous studies on $\mathrm{C}-\mathrm{C}$ bond forming cross-couplings, we found that the origin of the rapeseed oil has little influence on the efficiency of the reactions. ${ }^{8 a}$ However, for Buchwald-Hartwig amination, an initial screening of rapeseed oils showed that the results were significantly dependent on the choice of supplier (Chart 1, orange columns). Quantitative yields were only maintained in rapeseed oils from Odelia (97\%) and Anglamark (99\%). For all the other rapeseed oils, the yields went down significantly (Coop (23\%), Rema (43\%), Sigma-Aldrich $(26 \%))$.

In addition to rapeseed oils we examined the performance of nine vegetable oils (orange columns), two triglycerides originating from animals (pink columns), semisynthetic triacetin and tributyrin (green columns), ${ }^{10}$ and three natural waxes (blue columns) (Chart 1). When other types of lipids were tested as solvents, similar varying yields were observed. Low yields were found for sunflower oils (18-34\%), soybean oils $(26-44 \%)$, corn oil (51\%), avocado oil (43\%), a mixture of oils $(63 \%)$, and fish oil (14\%), while good to quantitative yields were obtained in triacetin (92\%), tributyrin (100\%), olive oil $(100 \%)$, sesame oil $(88 \%)$, rice bran oil $(81 \%)$, coconut oil (99\%), butter (99\%), fish oil from Sigma-Aldrich $(82 \%)$, and waxes $(95-100 \%)$ (Chart 1). Changing the catalyst or catalyst loading did not improve the low yields (Table S3 in the Supporting Information), which prompted us to examine the existence and effects of various ingredients present in natural lipids.

A HRMS analysis of rapeseed oil from Askim showed the presence of glycerol, free fatty acids, monoglycerides, and diglycerides. These compounds are amphiphiles that can act as surfactants, thus improving the solubility of the base and other ingredients of the reaction in oils. ${ }^{11}$ Fatty acids can react with the base $\left(\mathrm{K}_{2} \mathrm{CO}_{3}\right)$, generating corresponding potassium salts, which have improved solubility in fats and can act as shuttle bases or phase transfer catalysts. Amphiphiles can form reversed micelles ${ }^{12}$ that have been shown to act as microreactors for Pd-catalyzed transformations. ${ }^{13}$ Accordingly, we 


\section{Chart 1. Screening of Solvents for Buchwald-Hartwig Amination ${ }^{a}$}

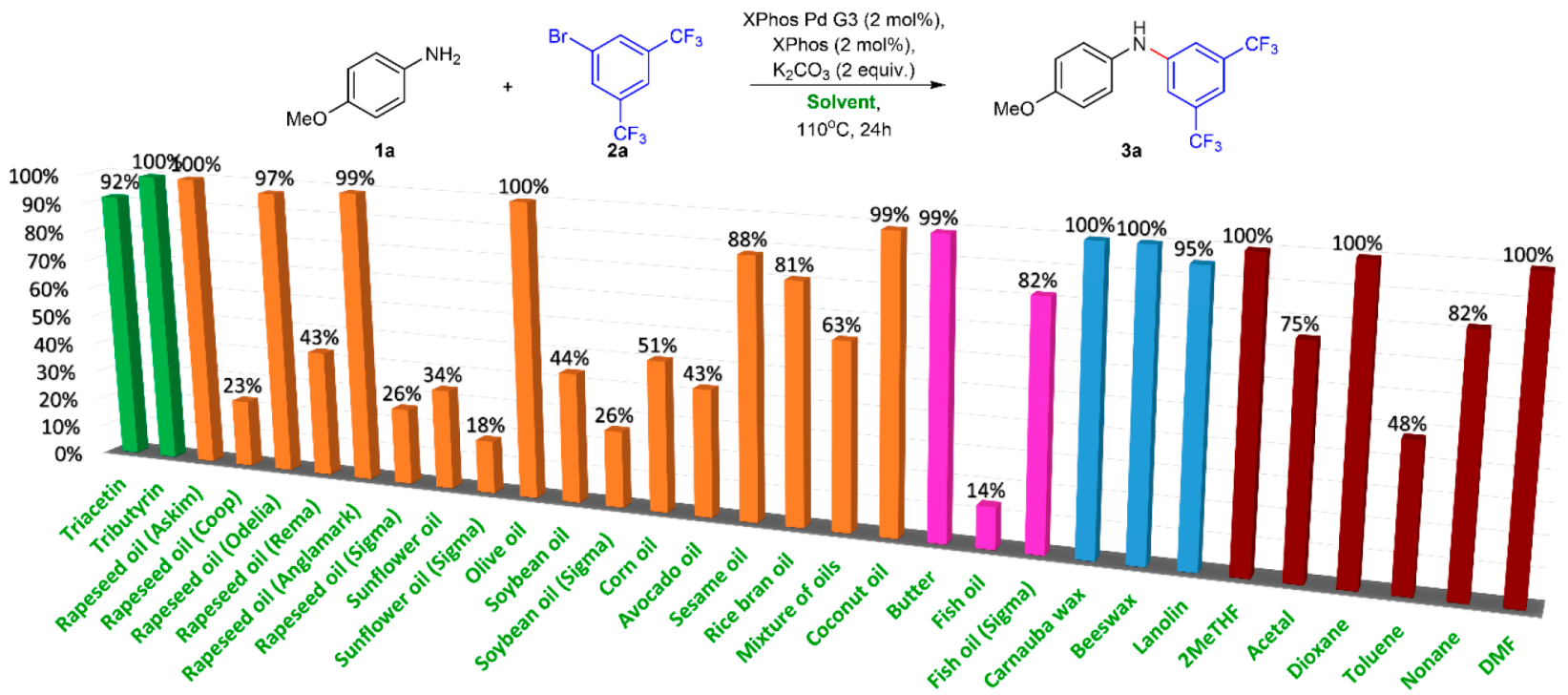

${ }^{a}$ Yields were determined by ${ }^{1} \mathrm{H}$ NMR using 1,3,5-trimethoxybenzene as an internal standard.

\section{Chart 2. Screening of Additives for Buchwald-Hartwig Amination ${ }^{d}$}

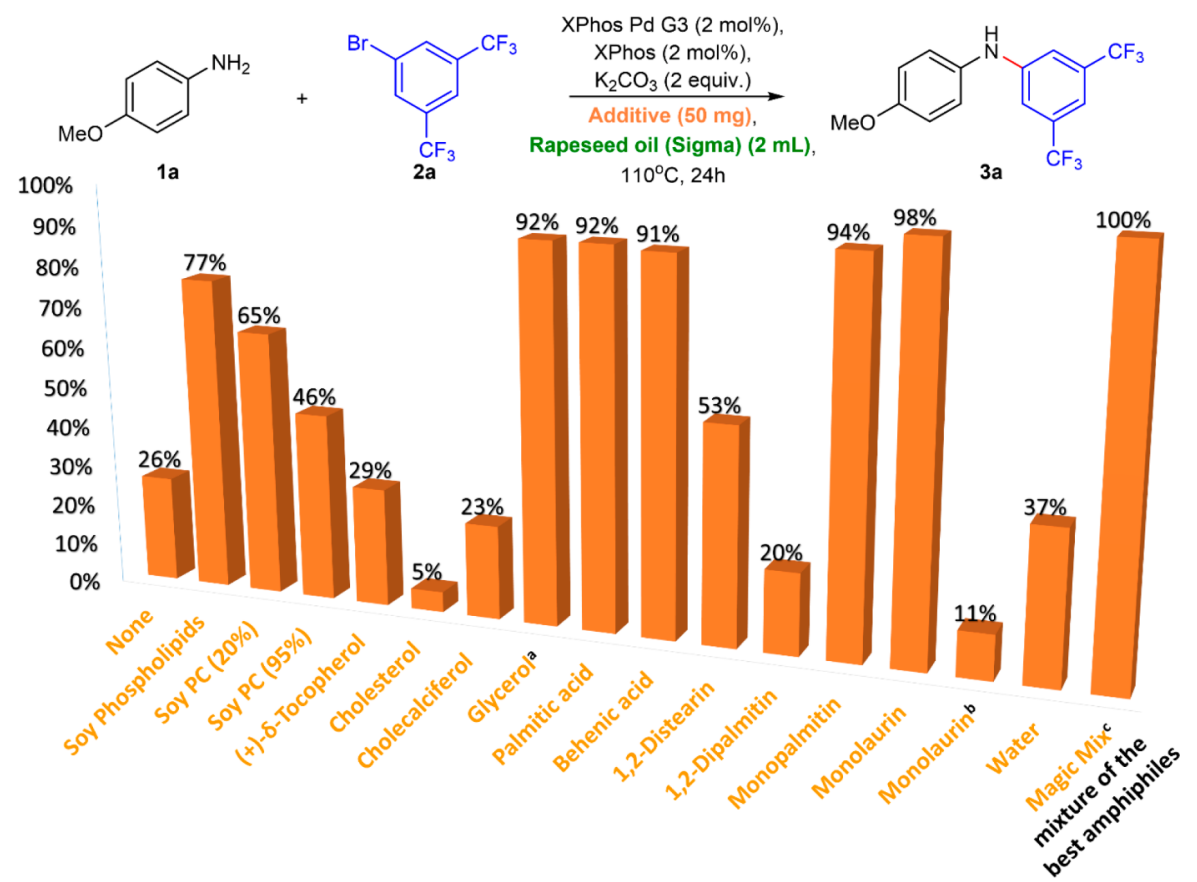

${ }^{a}$ The quantity of glycerol was 1 drop. ${ }^{b}$ The quantity of monolaurin was $10 \mathrm{mg}$. ${ }^{c}$ Magic Mix consists of a mixture of soy phospholipids $(5 \mathrm{mg})$, soy PC (20\%) (5 mg), glycerol (1 drop), palmitic acid $(5 \mathrm{mg})$, behenic acid (5 mg), monopalmitin (5 mg), and monolaurin (5 mg). ${ }^{d}$ Yields were determined by ${ }^{1} \mathrm{H}$ NMR using 1,3,5-trimethoxybenzene as an internal standard. All experiments were performed in rapeseed oil from Sigma-Aldrich $(2 \mathrm{~mL})$ using $0.683 \mathrm{mmol}(200 \mathrm{mg})$ of the limiting reagent (aryl halide $2 \mathrm{a})$.

set a series of control experiments to investigate the effect of various commercially available natural amphiphiles $(50 \mathrm{mg})$ on the reaction in rapeseed oil $(2 \mathrm{~mL})$ from Sigma-Aldrich (Chart 2 ). Our focus was on amphiphiles found in lipids and originating from vegetable oils, such as phospholipids, the products of hydrolysis of triglycerides, and fat-soluble vitamins (for a detailed description of the additives used, see general considerations in the Supporting Information). ${ }^{11}$

Initial trials with three different sets of phospholipids (soy phospholipids, soy PC (20\%), and soy PC (95\%)) used as additives showed notable improvements in yields (from $26 \%$ to $77 \%$ ). A considerable increase in yields of Buchwald-Hartwig amination reaction was observed when glycerol (92\%), fatty acids such as palmitic acid (92\%) and behenic acid (91\%), and monoglycerides such as monopalmitin (94\%) and monolaurin (98\%) were used. On the other hand, $(+)-\delta$-tocopherol $(29 \%)$, cholesterol (5\%), and cholecalciferol (23\%) were not effective, and the same was observed with diglycerides, such as 1,2distearin (53\%) and 1,2-dipalmitin (20\%). Addition of water 
Chart 3. Buchwald-Hartwig Amination in the Presence of the Magic Mix ${ }^{a}$

- Yields of Buchwald-Hartwig amination in lipids and common solvents

- Yields of the reactions performed in the presence of the Magic Mix<smiles>COc1ccc(Nc2cc(C(F)(F)F)cc(C(F)(F)F)c2)cc1</smiles>

1a

$2 \mathrm{a}$ $110^{\circ} \mathrm{C}, 24 \mathrm{~h}$

3a

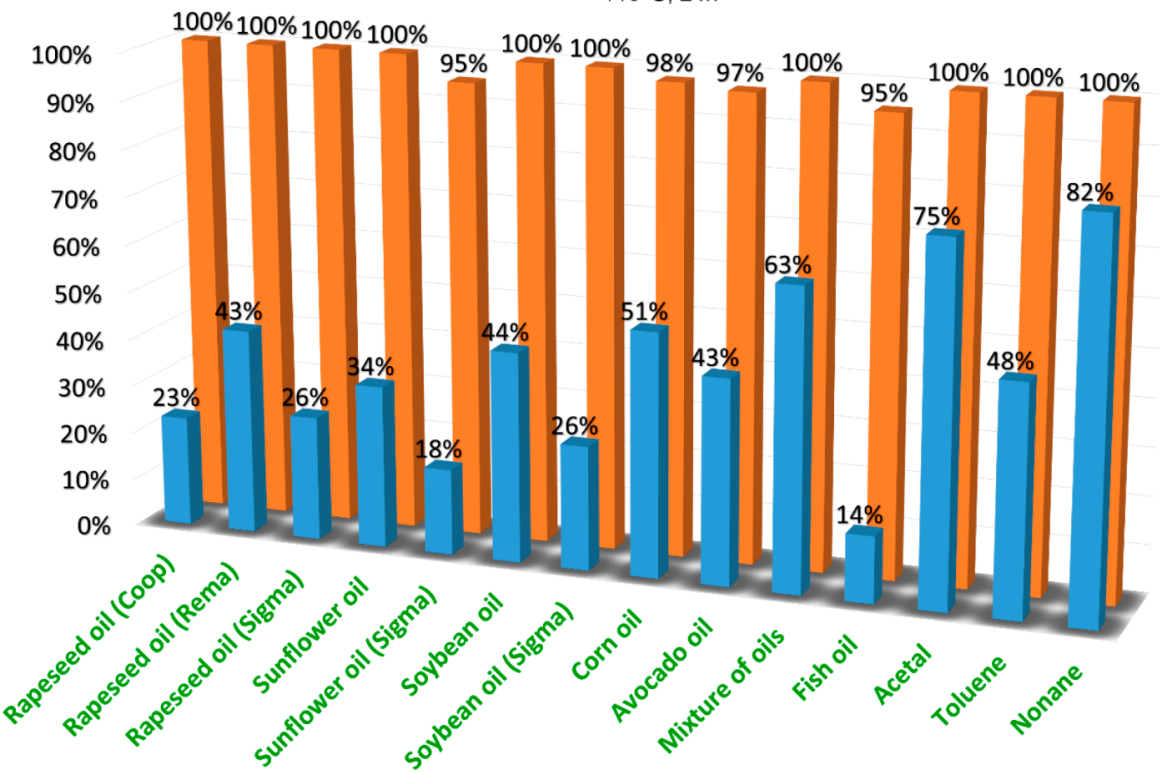

${ }^{a}$ See Chart 2. Yields were determined by ${ }^{1} \mathrm{H}$ NMR using 1,3,5-trimethoxybenzene as an internal standard.

Scheme 1. Influence of the Magic Mix on Hiyama (A) and Heck (B) Cross-Couplings ${ }^{a}$

(A) The influence of the Magic Mix on Hiyama coupling
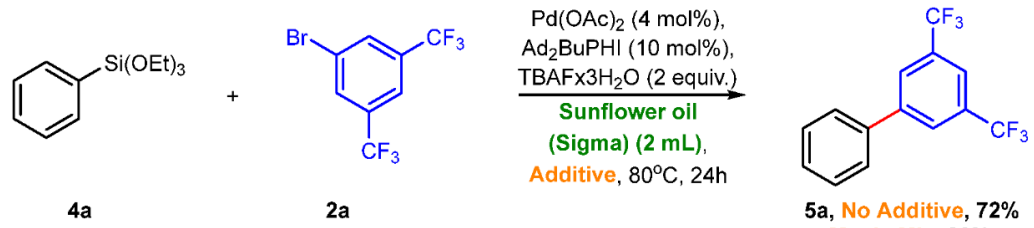

(B) The influence of the Magic Mix on Heck coupling
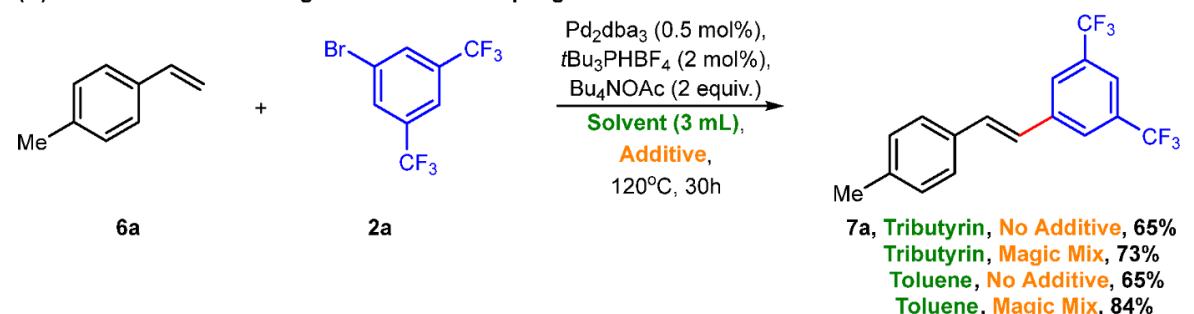

${ }^{a}$ Yields were determined by ${ }^{1} \mathrm{H}$ NMR.

slightly improved the yield (37\%), probably due to partial hydrolysis generating amphiphiles.

Eventually, we found that a combination of the best additives, including soy phospholipids $(5 \mathrm{mg})$, soy PC $(20 \%)$ (5 mg), glycerol (1 drop), palmitic acid ( $5 \mathrm{mg})$, behenic acid (5 mg), monopalmitin (5 mg), and monolaurin ( $5 \mathrm{mg}$ ) (Magic Mix $)$ in rapeseed oil ( $2 \mathrm{~mL})$ from Sigma-Aldrich, increases the yield of the reaction from $26 \%$ to quantitative. The combination of additives (Magic Mix) was also effective in increasing the yields in other lipids such as sunflower oil and soybean oil from $34 \%$ and $44 \%$, respectively, to quantitative (Chart 3, orange columns).

Intrigued by the good effect of the Magic Mix on the yield of Buchwald-Hartwig amination in lipids, we tested the Magic Mix as an additive for reactions in traditional and green solvents, which gave unsatisfactory results. We were pleased to find that the low yields of Buchwald-Hartwig aminations in acetal (1,1-diethoxyethane, from $75 \%$ to $100 \%$ yield), toluene (from $48 \%$ to $100 \%$ yield), and nonane (from $82 \%$ to $100 \%$ yield) can be significantly improved (Chart 3 ). 
Chart 4. Buchwald-Hartwig Amination in Waste and Inedible Oils ${ }^{a}$

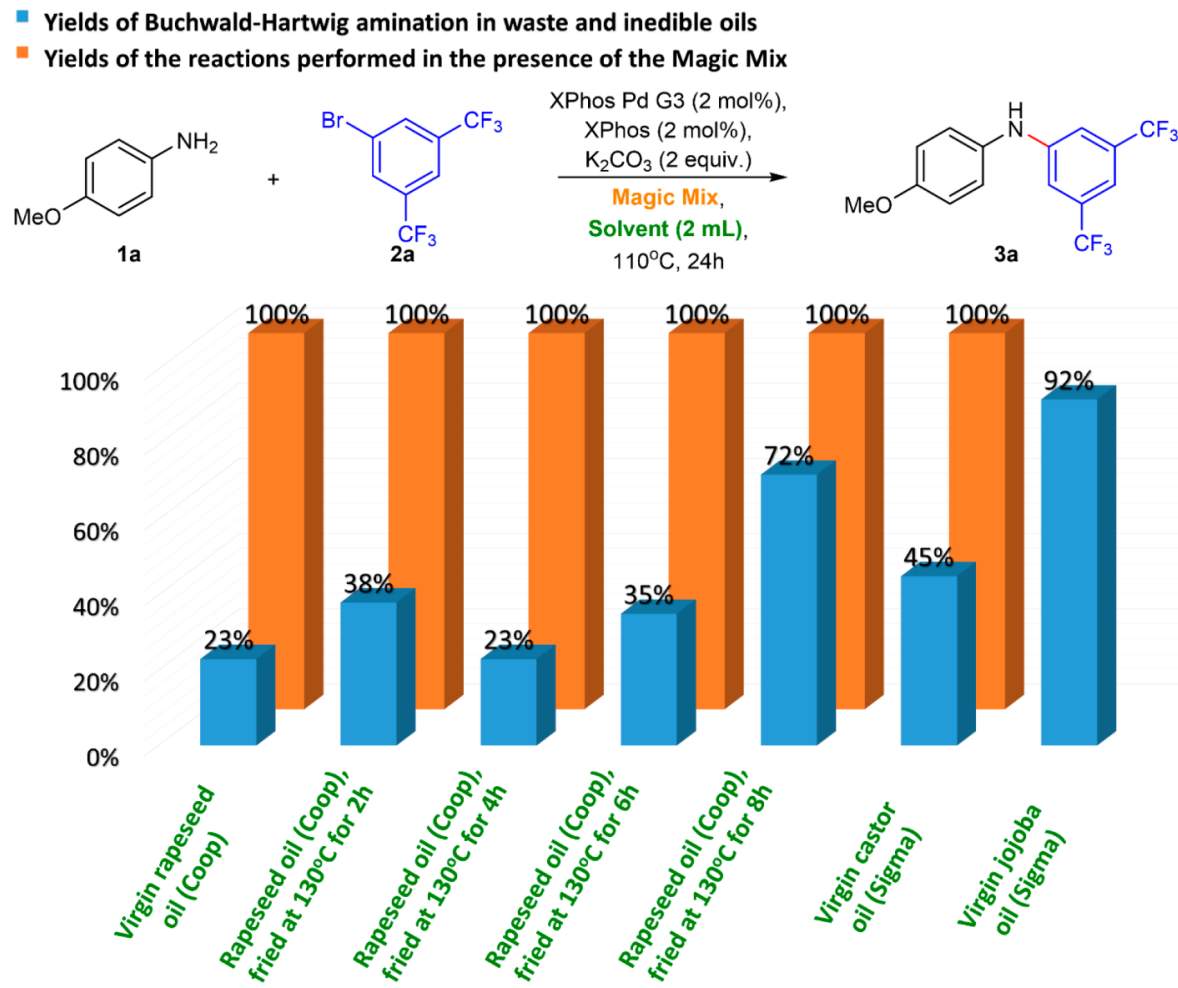

${ }^{a}$ Yields were determined by ${ }^{1} \mathrm{H}$ NMR using 1,3,5-trimethoxybenzene as an internal standard.

The influence of the Magic Mix on the outcome of other low-yielding cross-couplings in lipids, ${ }^{8 a}$ such as Hiyama and a Heck cross-coupling reactions, was briefly examined (Scheme 1). For these transformations, the improvement in yield due to the addition of the Magic Mix was between $10 \%$ and $20 \%$. The yield of the Hiyama cross-coupling of phenyltriethoxysilane (4a) and 3,5-bis(trifluoromethyl)bromobenzene (2a) in sunflower oil from Sigma-Aldrich was increased from $72 \%$ yield (no additive) to $80 \%$ (with the Magic Mix) (Scheme 1A). The yield of the Heck coupling of $p$-methylstyrene (6a) performed in tributyrin or toluene was improved from $65 \%$ to $73 \%$ and from $65 \%$ to $84 \%$ using the Magic Mix, respectively (Scheme 1B). A near $20 \%$ increase in the yield of stilbene derivative (7a), observed in toluene, illuminates the potential of the Magic Mix for other reactions and traditional solvents.

The majority of examined vegetable oils described above were food grade. To avoid a competition between the need for food and chemicals, we examined waste rapeseed oils, along with inedible castor and jojoba oils (Chart 4). Waste rapeseed oils were obtained by frying potatoes at $130{ }^{\circ} \mathrm{C}$ for $2,4,6$, and $8 \mathrm{~h}$, respectively, in rapeseed oil of the brand Coop (for details see general considerations in the Supporting Information). The yields of Buchwald-Hartwig amination in waste rapeseed oils used for frying for 2,4 , and $6 \mathrm{~h}$ were close to the yield observed for the corresponding virgin rapeseed oil (23-38\%). However, the yield of the reaction in waste rapeseed oil used for frying for $8 \mathrm{~h}$ was increased to $72 \%$, probably due to the formation of amphiphiles by partial oxidation and hydrolysis during frying. Addition of the Magic Mix to the reactions in waste rapeseed oils increased the yields to quantitative (Chart 4 , orange columns). In the case of inedible oils, the yield of Buchwald-Hartwig amination performed in jojoba oil was
$92 \%$, while the $45 \%$ yield obtained in castor oil could be increased to quantitative by application of the Magic Mix.

Eventually, we analyzed the scope and limitations of the Buchwald-Hartwig amination in lipids as solvents. First, we identified the most efficient catalytic systems for unactivated aryl halides and sulfonates (Table S5 in the Supporting Information). Here, the best yields were reached when a BrettPhos Pd G3/BrettPhos- or $t$ BuXPhos Pd G3/tBuXPhosbased catalytic system was used. Using these catalysts, good yields were obtained for various nucleophiles, such as primary anilines (3a-c; 94-99\%) and heterocycles like indole and pyrrole (3g,h; 65-91\%) (Scheme 2). Satisfactory yields were observed for secondary anilines (3d,e; 55-62\%), primary amines (3f, $50 \%)$ and phenols (3i; $56 \%)$. Attempts to improve the yields for a tertiary aniline $(3 \mathbf{e} ; 51 \%)$ and an ether (3i; $57 \%$ ) by the use of the Magic Mix were not successful. Screening of aryl halides and sulfonates showed that the developed methodology can be an excellent tool for the production of secondary anilines in quantitative yields (Scheme 2). Both electron-rich (3j-m; 96-99\%) and electron-deficient (3n,o; 97-99\%) aryl bromides and chlorides as well as aryl triflates gave excellent results. The yields of Buchwald-Hartwig amination were moderate only in the case of electron-rich and labile heterocycles ( $3 p, q ; 49-71 \%)$, such as 3-bromothiophene and 2-bromobenzothiophene. For the last two systems, the amination products are highly unstable and must be stored in the freezer.

\section{CONCLUSIONS}

We have shown that Buchwald-Hartwig aminations can be successfully realized in vegetable oils, triglycerides originating from animals and natural waxes as solvents. The presented results highlight the excellent performance of safe and cheap 
Scheme 2. Scope of Buchwald-Hartwig Amination in Rapeseed Oil from Askim ${ }^{a}$

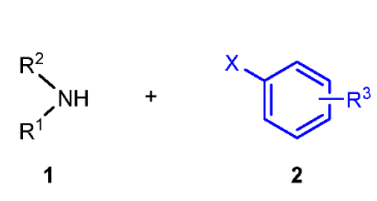

Method A: XPhos Pd G3 (2 mol\%)

XPhos ( 2 mol\%), $\mathrm{K}_{2} \mathrm{CO}_{3}$ (2 equiv.),

Rapeseed oil (Askim), $110^{\circ} \mathrm{C}, 24 \mathrm{~h}$

Method B: tBuXPhos Pd G3 (2 mol\%), tBuXPhos (2 mol\%), $\mathrm{K}_{2} \mathrm{CO}_{3}$ (2 equiv.)

Rapeseed oil (Askim), $110^{\circ} \mathrm{C}, 24 \mathrm{~h}$<smiles>[R][14c]1cccc(N([R])[R])c1</smiles>

3<smiles>COc1ccc(Nc2cc(C(F)(F)F)cc(C(F)(F)F)c2)cc1C(F)(F)F</smiles><smiles>Cc1ccc(Nc2cc(C(F)(F)F)cc(C(F)(F)F)c2)cc1</smiles>

3a, Method

3b, Method A

$\mathrm{X}=\mathrm{Br}, 99 \%$ $\mathrm{X}=\mathrm{Br}, \mathbf{9 4 \%}$

c, Method A<smiles>CN(c1ccccc1)c1cc(C(F)(F)F)cc(C(F)(F)F)c1</smiles>

d, Method $A$

$\mathrm{X}=\mathrm{Br}, 62 \%$<smiles>FC(F)(F)c1cc(N(c2ccccc2)c2ccccc2)cc(C(F)(F)F)c1</smiles>

3e, Method A Method B $\mathrm{X}=\mathrm{Br}, \mathbf{5 5 \%} \quad \mathrm{X}=\mathrm{Br}, \mathbf{0} \%$<smiles>FC(F)(F)c1cc(NCc2ccccc2)cc(C(F)(F)F)c1</smiles>

3f, Method A Method B $\mathrm{X}=\mathrm{Br}, \mathbf{5 0} \% \mathrm{X}=\mathrm{Br}, \mathbf{0} \%$<smiles>FC(F)(F)c1cc(-n2ccc3ccccc32)cc(C(F)(F)F)c1</smiles>

3 g, Method A<smiles>FC(F)(F)c1cc(-n2cccc2)cc(C(F)(F)F)c1</smiles><smiles>Cc1ccc(Oc2cc(C(F)(F)F)cc(C(F)(F)F)c2)cc1</smiles>

$\mathrm{X}=\mathrm{Br}, \mathbf{9 1} \%$

$3 h$, Method A
$X=B r, 65 \%$

3i, Method A Method B $\mathrm{X}=\mathrm{Br}, \mathbf{2 8} \% \quad \mathrm{X}=\mathrm{Br}, \mathbf{5 6} \%$<smiles>Cc1ccc(Nc2ccccc2C)cc1</smiles><smiles>Cc1ccc(Nc2ccc(C)cc2)cc1</smiles><smiles>Cc1ccc(Nc2ccccc2)cc1</smiles>

$3 \mathrm{j}$, Method $\mathrm{B}$
$\mathrm{X}=\mathrm{Br}, 96 \%$

3k, Method B

$\mathrm{X}=\mathrm{Br}, \mathbf{9 9 \%}$

3I, Method B

$\mathrm{X}=\mathrm{Cl}, \mathbf{9 8 \%}$<smiles>Cc1ccc(Nc2ccc3ccccc3c2)cc1</smiles><smiles>Cc1ccc(Nc2ccc(C(F)(F)F)cc2)cc1</smiles>

Me<smiles>FC(F)(F)c1cccc(Nc2ccc(Cl)cc2)c1</smiles>

3n, Method B

$\mathrm{X}=\mathrm{Br}, 99 \%$

3o, Method B $\mathrm{X}=\mathrm{Br}, 96 \%$ $\mathrm{X}=\mathrm{Cl}, 99 \%$

$\mathrm{X}=\mathrm{Br}, 97 \%$<smiles>Cc1ccc(Nc2ccsc2)cc1</smiles>

3p, Method B<smiles>Cc1ccc(Nc2cc3ccccc3s2)cc1</smiles>

3q, Method B

${ }^{a_{T}}$ The yields refer to isolated products.

lipids as replacements for traditional solvents. Unlike other cross-couplings, the Buchwald-Hartwig amination is very sensitive to the nature of the used solvents. Our studies indicate that small quantities of hydrolysis products from triglycerides as well as phospholipids can have a decisive effect on the efficiency of Buchwald-Hartwig amination. On the basis of this observation, we introduced a mixture of amphiphiles, originating from triglycerides, which can be used to improve the performance of Buchwald-Hartwig aminations and other cross-couplings in both lipids and classical organic solvents.

\section{EXPERIMENTAL SECTION}

General Considerations. Commercially available starting materials, reagents, catalysts, and anhydrous and degassed solvents were used without further purification. Flash column chromatography was performed with Merck silica gel 60 (230-400 mesh). The solvents for column chromatography were distilled before use (in the case of technical solvents). Thin-layer chromatography was carried out using Merck TLC silica gel $60 \mathrm{~F}_{254}$ and visualized by short-wavelength ultraviolet light or by treatment with potassium permanganate $\left(\mathrm{KMnO}_{4}\right)$ staining. ${ }^{1} \mathrm{H},{ }^{13} \mathrm{C}$, and ${ }^{19} \mathrm{~F}$ NMR spectra were recorded on a Bruker Avance $400 \mathrm{MHz}$ spectrometer at $20{ }^{\circ} \mathrm{C}$. All ${ }^{1} \mathrm{H}$ NMR spectra are reported in parts per million (ppm) downfield of TMS and were measured relative to the signal for $\mathrm{CHCl}_{3}(7.26 \mathrm{ppm})$. All ${ }^{13} \mathrm{C}$ $\mathrm{NMR}$ spectra are reported in ppm relative to residual $\mathrm{CDCl}_{3}(77.20$ 
ppm) and were obtained with ${ }^{1} \mathrm{H}$ decoupling. Coupling constants, $J$, are reported in Hertz $(\mathrm{Hz})$. High-resolution mass spectra (HRMS) were recorded from methanol solutions on an LTQ Orbitrap XL (Thermo Scientific) in either negative or positive electrospray ionization (ESI) mode.

General Experimental Procedure for Buchwald-Hartwig Amination. Method A. Inside of an Ar-filled glovebox an oven-dried $10 \mathrm{~mL}$ flask was sequentially charged with XPhos Pd G3 (2 mol \%), XPhos ( $2 \mathrm{~mol} \%), \mathrm{K}_{2} \mathrm{CO}_{3}$ (2 equiv), and the appropriate nucleophile (1.5 equiv). The flask was sealed with a rubber septum, removed from the glovebox, and equipped with an Ar balloon. Next, rapeseed oil from Askim $(2 \mathrm{~mL})$ and the corresponding aryl halide (1 equiv, 0.683 mmol) were added sequentially. The Ar balloon was removed, and the resulting mixture was stirred at $110{ }^{\circ} \mathrm{C}$ for $24 \mathrm{~h}$. Afterward, the reaction mixture was cooled, which was followed by isolation of the product according to one of the following methods.

(I) The reaction mixture was transferred onto the top of a column, filled with silica gel, using a disposable Pasteur pipet. The reaction vial was washed with $1 \mathrm{~mL}$ of DCM that was diluted with $1 \mathrm{~mL}$ of heptane and transferred onto the top of the column. This was followed by a classical column separation using mixtures of heptane as eluent. Rapeseed oil can be washed out from the column using ethyl acetate, dried, and applied for another experiment. NMR spectra of the rapeseed oil before and after the reaction were identical.

(II) The flask containing the reaction mixture was attached to a short-path vacuum distillation apparatus (Kugelrohr) and heated to $250{ }^{\circ} \mathrm{C}$ under reduced pressure. The product was condensed in the receiving bulb within $40-60 \mathrm{~min}$. If necessary, the condensed product could be further purified by column chromatography. Rapeseed oil from the flask containing the reaction mixture could be filtered through a short pad of silica gel using ethyl acetate, dried, and applied for another experiment. NMR spectra of rapeseed oil before and after the reaction were identical.

(III) The reaction mixture was transferred into a $250 \mathrm{~mL}$ roundbottom flask. The reaction vial was washed using EtOAc or THF and transferred into the $250 \mathrm{~mL}$ flask containing the reaction mixture. Afterward, the volatiles were removed using a rotary evaporator followed by addition of $40 \mathrm{~mL}$ of a $5 \mathrm{M}$ $\mathrm{NaOH}$ solution. The flask was equipped with a condenser and stirred under reflux for $4 \mathrm{~h}$. The resulting mixture was treated with $100 \mathrm{~mL}$ of saturated $\mathrm{NaCl}$ solution, transferred into a 500 $\mathrm{mL}$ separating funnel, and extracted with DCM $(3 \times 50 \mathrm{~mL})$. The organic fractions were collected, evaporated to dryness, and further purified using column chromatography.

Method B. Inside of an Ar-filled glovebox an oven-dried $10 \mathrm{~mL}$ flask was sequentially charged with $t$ BuXPhos Pd G3 (2 mol \%), $t$ BuXPhos ( 2 mol \%), $\mathrm{K}_{2} \mathrm{CO}_{3}$ (2 equiv), and the appropriate nucleophile ( 1.5 equiv). The flask was sealed with a rubber septum, removed from the glovebox, and equipped with an Ar balloon. Next, rapeseed oil from Askim ( $3 \mathrm{~mL}$ ) and the corresponding aryl halide/ sulfonate ester ( 1 equiv, $0.869-0.948 \mathrm{mmol}$ ) were added sequentially. The Ar balloon was removed, and the resulting mixture was stirred at $110{ }^{\circ} \mathrm{C}$ for $24 \mathrm{~h}$. Afterward, the reaction mixture was cooled, which was followed by isolation of the product according to one of the methods described in Method A.

Characterization of Products. N-(4-Methoxyphenyl)-3,5-bis(trifluoromethyl)aniline (3a). Starting from $0.683 \mathrm{mmol}$ of the corresponding aryl halide, the product was obtained as a white solid: yield $99 \%\left(0.228 \mathrm{~g}\right.$, method A). ${ }^{1} \mathrm{H}$ NMR $\left(400 \mathrm{MHz}, \mathrm{CDCl}_{3}\right): \delta 3.66$ (s, 3H, OMe), 5.66 (br s, 1H, NH), 6.75-6.79 (m, 2H, Ar), 6.93$6.97(\mathrm{~m}, 2 \mathrm{H}, \mathrm{Ar}), 7.00(\mathrm{~s}, 2 \mathrm{H}, \mathrm{Ar}), 7.07(\mathrm{~s}, 1 \mathrm{H}, \mathrm{Ar}) .{ }^{13} \mathrm{C}$ NMR $(101$ $\left.\mathrm{MHz}, \mathrm{CDCl}_{3}\right): \delta 55.7,111.9$ (hept, $\left.J=4.0 \mathrm{~Hz}\right), 113.8(\mathrm{q}, J=3.8 \mathrm{~Hz})$, $115.3,123.7(\mathrm{q}, J=271 \mathrm{~Hz}), 124.8,132.8(\mathrm{q}, J=33 \mathrm{~Hz}), 133.0$, 147.3, 157.2. HRMS-EI $(\mathrm{m} / z):[\mathrm{M}+\mathrm{H}]^{+}$calcd for $\mathrm{C}_{15} \mathrm{H}_{12} \mathrm{~F}_{6} \mathrm{NO}$ 336.0818 , found 336.0823 .

3,5-Bis(trifluoromethyl)- $N$-(3-(trifluoromethyl)phenyl)aniline (3b). Starting from $0.683 \mathrm{mmol}$ of the corresponding aryl halide, the product was obtained as a colorless oil: yield $94 \%(0.239 \mathrm{~g}$, method A). ${ }^{1} \mathrm{H}$ NMR $\left(400 \mathrm{MHz}, \mathrm{CDCl}_{3}\right): \delta 6.11(\mathrm{br} \mathrm{s}, 1 \mathrm{H}, \mathrm{NH}), 7.33-7.36$ (m, 3H, Ar), $7.44(\mathrm{~s}, 3 \mathrm{H}, \mathrm{Ar}), 7.49(\mathrm{t}, J=7.8 \mathrm{~Hz}, 1 \mathrm{H}, \mathrm{Ar}) .{ }^{13} \mathrm{C} \mathrm{NMR}$ $\left(101 \mathrm{MHz}, \mathrm{CDCl}_{3}\right): \delta 114.5$ (hept, $\left.J=3.9 \mathrm{~Hz}\right), 116.3-116.5(\mathrm{~m})$, $120.1(\mathrm{q}, J=3.8 \mathrm{~Hz}), 122.5,123.4(\mathrm{q}, J=271 \mathrm{~Hz}), 124.0(\mathrm{q}, J=270$ $\mathrm{Hz}), 130.6,132.6(\mathrm{q}, J=32 \mathrm{~Hz}), 133.2(\mathrm{q}, J=33 \mathrm{~Hz}), 141.6,144.4$. HRMS-EI $(\mathrm{m} / z):[\mathrm{M}+\mathrm{H}]^{+}$calcd for $\mathrm{C}_{15} \mathrm{H}_{9} \mathrm{~F}_{9} \mathrm{~N}$ 374.0586, found 374.0583 .

$\mathrm{N}$-(p-Tolyl)-3,5-bis(trifluoromethyl)aniline (3c). Starting from $0.683 \mathrm{mmol}$ of the corresponding aryl halide, the product was obtained as a white solid: yield $97 \%\left(0.211 \mathrm{~g}\right.$, method A). ${ }^{1} \mathrm{H}$ NMR $\left(400 \mathrm{MHz}, \mathrm{CDCl}_{3}\right): \delta 2.40$ (s, 3H, Me), 5.89 (br s, $\left.1 \mathrm{H}, \mathrm{NH}\right), 7.09$ (d, $J=8.1 \mathrm{~Hz}, 2 \mathrm{H}, \mathrm{Ar}), 7.23(\mathrm{~d}, J=8.0 \mathrm{~Hz}, 2 \mathrm{H}, \mathrm{Ar}), 7.32(\mathrm{~s}, 3 \mathrm{H}, \mathrm{Ar}) .{ }^{13} \mathrm{C}$ NMR $\left(101 \mathrm{MHz}, \mathrm{CDCl}_{3}\right): \delta 20.9,112.5$ (hept, $\left.J=4.0 \mathrm{~Hz}\right), 114.6(\mathrm{q}$, $J=4.0 \mathrm{~Hz}), 121.6,123.6(\mathrm{q}, J=271 \mathrm{~Hz}), 130.6,132.8(\mathrm{q}, J=32.9$ $\mathrm{Hz}), 134.2,137.7,146.3$.

N-Methyl-N-phenyl-3,5-bis(trifluoromethyl)aniline (3d). Starting from $0.683 \mathrm{mmol}$ of the corresponding aryl halide, the product was obtained as a white solid: yield $62 \%\left(0.134 \mathrm{~g}\right.$, method A). ${ }^{1} \mathrm{H}$ NMR $\left(400 \mathrm{MHz}, \mathrm{CDCl}_{3}\right): \delta 3.37$ (s, 3H, NMe), 7.14 (s, 2H, Ar), 7.18$7.20(\mathrm{~m}, 2 \mathrm{H}, \mathrm{Ar}), 7.22-7.26(\mathrm{~m}, 2 \mathrm{H}, \mathrm{Ar}), 7.40-7.46(\mathrm{~m}, 2 \mathrm{H}, \mathrm{Ar})$. ${ }^{13} \mathrm{C} \mathrm{NMR}\left(101 \mathrm{MHz}, \mathrm{CDCl}_{3}\right): \delta 40.6,111.2(\mathrm{p}, J=3.9 \mathrm{~Hz}), 114.4(\mathrm{q}$, $J=4.0 \mathrm{~Hz}), 123.8(\mathrm{q}, J=271 \mathrm{~Hz}), 125.7,126.0,130.4,132.4(\mathrm{q}, J=$ $32.7 \mathrm{~Hz}), 147.2,150.0$

$\mathrm{N}, \mathrm{N}$-Diphenyl-3,5-bis(trifluoromethyl)aniline (3e). Starting from $0.683 \mathrm{mmol}$ of the corresponding aryl halide, the product was obtained as a white solid: yield $55 \%(0.142 \mathrm{~g}$, method A), $0 \%(0 \mathrm{~g}$, method B). ${ }^{1} \mathrm{H}$ NMR $\left(400 \mathrm{MHz}, \mathrm{CDCl}_{3}\right): \delta 7.15-7.24(\mathrm{~m}, 6 \mathrm{H}, \mathrm{Ar})$, 7.34-7.43 (m, 7H, Ar). $\left.{ }^{13} \mathrm{C} \mathrm{NMR} \mathrm{(101} \mathrm{MHz,} \mathrm{CDCl}_{3}\right): \delta 114.2(\mathrm{p}, J$ $=4.0 \mathrm{~Hz}), 120.5(\mathrm{q}, J=4.0 \mathrm{~Hz}), 123.5(\mathrm{q}, J=271 \mathrm{~Hz}), 125.2,125.6$, $130.1,132.6(\mathrm{q}, J=33.0 \mathrm{~Hz}), 146.3,149.5$.

$\mathrm{N}$-Benzyl-3,5-bis(trifluoromethyl)aniline (3f). Starting from 0.683 $\mathrm{mmol}$ of the corresponding aryl halide, the product was obtained as a colorless oil: yield 50\% (0.109 g, method A), $0 \%(0$ g, method B $) .{ }^{1} \mathrm{H}$ $\operatorname{NMR}\left(400 \mathrm{MHz}, \mathrm{CDCl}_{3}\right): \delta 4.38-4.46\left(\mathrm{~m}, 3 \mathrm{H}, \mathrm{CH}_{2} / \mathrm{NH}\right), 6.99(\mathrm{~s}$, $2 \mathrm{H}, \mathrm{Ar}), 7.19$ (s, 1H, Ar), 7.32-7.42 (m, 5H, Ar). ${ }^{13} \mathrm{C}$ NMR (101 $\left.\mathrm{MHz}_{\mathrm{CDCl}}\right): \delta 48.2,110.6(\mathrm{p}, J=4.0 \mathrm{~Hz}), 112.1(\mathrm{q}, J=4.0 \mathrm{~Hz})$, $123.7(\mathrm{q}, J=271 \mathrm{~Hz}), 127.8,128.1,129.1,132.6(\mathrm{q}, J=32.8 \mathrm{~Hz})$, 137.8, 148.8 .

1-(3,5-Bis(trifluoromethyl)phenyl)-1H-indole (3g). Starting from $0.683 \mathrm{mmol}$ of the corresponding aryl halide, the product was obtained as a white solid: yield $91 \%\left(0.204 \mathrm{~g}\right.$, method A). ${ }^{1} \mathrm{H}$ NMR $\left(400 \mathrm{MHz}, \mathrm{CDCl}_{3}\right): \delta 6.80(\mathrm{~d}, J=3.4 \mathrm{~Hz}, 1 \mathrm{H}, \mathrm{Ar}), 7.25-7.29(\mathrm{~m}$, $1 \mathrm{H}, \mathrm{Ar}), 7.30-7.38$ (m, 2H, Ar), 7.58 (d, $J=8.2 \mathrm{~Hz}, 1 \mathrm{H}, \mathrm{Ar}), 7.74$ (d, $J=7.7 \mathrm{~Hz}, 1 \mathrm{H}, \mathrm{Ar}), 7.90$ (s, 1H, Ar), 8.02 (s, 2H, Ar). ${ }^{13} \mathrm{C}$ NMR (101 $\left.\mathrm{MHz}, \mathrm{CDCl}_{3}\right): \delta 106.1,109.9,119.8(\mathrm{p}, J=3.8 \mathrm{~Hz}), 121.7,121.9$, $123.1(\mathrm{q}, J=271 \mathrm{~Hz}), 123.7,124.0(\mathrm{q}, J=3.7 \mathrm{~Hz}), 127.3,130.0$, $133.5(\mathrm{q}, J=33.8 \mathrm{~Hz}), 135.6,141.5$.

1-(3,5-Bis(trifluoromethyl)phenyl)-1H-pyrrole (3h). Starting from $0.683 \mathrm{mmol}$ of the corresponding aryl halide, the product was obtained as a white solid: yield $65 \%\left(0.123 \mathrm{~g}\right.$, method A). ${ }^{1} \mathrm{H}$ NMR $\left(400 \mathrm{MHz}, \mathrm{CDCl}_{3}\right): \delta 6.44-6.45(\mathrm{~m}, 2 \mathrm{H}$, pyrrole), $7.15-7.16(\mathrm{~m}$, $2 \mathrm{H}$, pyrrole), $7.76(\mathrm{~s}, 1 \mathrm{H}, \mathrm{Ar}), 7.82(\mathrm{~s}, 2 \mathrm{H}, \mathrm{Ar}) .{ }^{13} \mathrm{C}$ NMR $(101 \mathrm{MHz}$, $\left.\mathrm{CDCl}_{3}\right): \delta 112.5,119.0(\mathrm{p}, J=3.8 \mathrm{~Hz}), 119.3,120.2(\mathrm{q}, J=4.0 \mathrm{~Hz})$, $123.2(\mathrm{q}, J=271 \mathrm{~Hz}), 133.4(\mathrm{q}, J=33.7 \mathrm{~Hz}), 142.0$.

1-(p-Tolyloxy)-3,5-bis(trifluoromethyl)benzene (3i). Starting from $0.683 \mathrm{mmol}$ of the corresponding aryl halide, the product was obtained as a colorless oil: yield $28 \%(0.062 \mathrm{~g}$, method A), $56 \%$ $\left(0.122 \mathrm{~g}\right.$, method B). ${ }^{1} \mathrm{H}$ NMR $\left(400 \mathrm{MHz}, \mathrm{CDCl}_{3}\right): \delta 2.40(\mathrm{~s}, 3 \mathrm{H}$, $\mathrm{Me}), 6.96-7.00(\mathrm{~m}, 2 \mathrm{H}, \mathrm{Ar}), 7.23-7.26(\mathrm{~m}, 2 \mathrm{H}, \mathrm{Ar}), 7.38(\mathrm{~s}, 2 \mathrm{H}$, $\mathrm{Ar}), 7.56(\mathrm{~s}, 1 \mathrm{H}, \mathrm{Ar}) \cdot{ }^{13} \mathrm{C}$ NMR $\left(101 \mathrm{MHz}, \mathrm{CDCl}_{3}\right): \delta 21.0,116.0$ (hept, $J=4.0 \mathrm{~Hz}), 117.6(\mathrm{q}, J=3.8 \mathrm{~Hz}), 120.2,123.2(\mathrm{q}, J=271 \mathrm{~Hz})$, $131.1,133.3$ (q, $J=33.6 \mathrm{~Hz}$ ), 135.3, 152.8, 159.5 .

2-Methyl-N-(p-tolyl)aniline (3j). Starting from $0.877 \mathrm{mmol}$ of the corresponding aryl halide, the product was obtained as a white solid: yield $96 \%\left(0.166 \mathrm{~g}\right.$, method B). ${ }^{1} \mathrm{H}$ NMR $\left(400 \mathrm{MHz}, \mathrm{CDCl}_{3}\right): \delta 2.34$ (s, 3H, Me), $2.40(\mathrm{~s}, 3 \mathrm{H}, \mathrm{Me}), 5.38(\mathrm{br} \mathrm{s}, 1 \mathrm{H}, \mathrm{NH}), 6.96-7.02(\mathrm{~m}$, $3 \mathrm{H}, \mathrm{Ar}), 7.16-7.23(\mathrm{~m}, 3 \mathrm{H}, \mathrm{Ar}), 7.26-7.28(\mathrm{~m}, 2 \mathrm{H}, \mathrm{Ar}) .{ }^{13} \mathrm{C}$ NMR $\left(101 \mathrm{MHz}, \mathrm{CDCl}_{3}\right): \delta 18.0,20.8,117.4,118.8,121.2,126.9,127.2$, 130.0, 130.5, 131.0, 141.2, 142.2. 
Di-p-tolylamine $(3 \boldsymbol{k})$. Starting from $0.877 \mathrm{mmol}$ of the corresponding aryl bromide and $0.948 \mathrm{mmol}$ of the corresponding aryl chloride, the product was obtained as a white solid: yield $99 \%$ (0.172 g, X = Br, method B), 99\% (0.185 g, $\mathrm{X}=\mathrm{Cl}$, method B). ${ }^{1} \mathrm{H}$ NMR $\left(400 \mathrm{MHz}, \mathrm{CDCl}_{3}\right): \delta 2.43(\mathrm{~s}, 6 \mathrm{H}, 2 \mathrm{xMe}), 5.54($ br s, $1 \mathrm{H}$, $\mathrm{NH}), 7.06-7.09$ (m, 4H, Ar), 7.18-7.21 (m, 4H, Ar). ${ }^{13} \mathrm{C}$ NMR (101 $\left.\mathrm{MHz}, \mathrm{CDCl}_{3}\right): \delta 20.7,118.0,129.9,130.2,141.3$.

4-Methyl-N-phenylaniline (3I). Starting from $0.888 \mathrm{mmol}$ of the corresponding aryl chloride and $0.884 \mathrm{mmol}$ of the corresponding aryl triflate, the product was obtained as a white solid: yield $98 \%(0.160 \mathrm{~g}$, $\mathrm{X}=\mathrm{Cl}$, method B), 99\% (0.160 g, X = OTf, method B). ${ }^{1} \mathrm{H}$ NMR $\left(400 \mathrm{MHz}, \mathrm{CDCl}_{3}\right): \delta 2.45(\mathrm{~s}, 3 \mathrm{H}, \mathrm{Me}), 5.66(\mathrm{br} \mathrm{s}, 1 \mathrm{H}, \mathrm{NH}), 7.00-$ $7.04(\mathrm{~m}, 1 \mathrm{H}, \mathrm{Ar}), 7.10-7.14(\mathrm{~m}, 4 \mathrm{H}, \mathrm{Ar}), 7.22(\mathrm{~d}, J=8.1 \mathrm{~Hz}, 2 \mathrm{H}$, Ar), 7.35-7.39 (m, 2H, Ar). ${ }^{13} \mathrm{C}$ NMR (101 MHz, $\left.\mathrm{CDCl}_{3}\right): \delta 20.8$, 117.0, 119.0, 120.4, 129.4, 130.0, 130.9, 140.4, 144.0.

$\mathrm{N}$-(p-Tolyl)naphthalen-2-amine (3m). Starting from $0.869 \mathrm{mmol}$ of the corresponding aryl halide, the product was obtained as a white solid: yield $96 \%\left(0.195 \mathrm{~g}\right.$, method B). ${ }^{1} \mathrm{H}$ NMR $\left(400 \mathrm{MHz}, \mathrm{CDCl}_{3}\right)$ : $\delta 2.44(\mathrm{~s}, 3 \mathrm{H}, \mathrm{Me}), 5.78($ br s, $1 \mathrm{H}, \mathrm{NH}), 7.16-7.18(\mathrm{~m}, 2 \mathrm{H}, \mathrm{Ar})$, $7.22-7.25(\mathrm{~m}, 3 \mathrm{H}, \mathrm{Ar}), 7.36-7.40(\mathrm{~m}, 1 \mathrm{H}, \mathrm{Ar}), 7.43(\mathrm{~d}, J=2.3 \mathrm{~Hz}$, $1 \mathrm{H}, \mathrm{Ar}), 7.47-7.51(\mathrm{~m}, 1 \mathrm{H}, \mathrm{Ar}), 7.71(\mathrm{~d}, J=8.2 \mathrm{~Hz}, 1 \mathrm{H}, \mathrm{Ar}), 7.81(\mathrm{t}$,

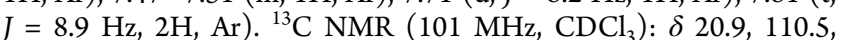
$119.5,119.7,123.3,126.5,126.5,127.8,129.0,129.2,130.1,131.5$, $134.8,140.2,141.8$.

4-Methyl-N-(4-(trifluoromethyl)phenyl)aniline (3n). Starting from $0.889 \mathrm{mmol}$ of the corresponding aryl bromide and $0.886 \mathrm{mmol}$ of the corresponding aryl chloride, the product was obtained as a white solid: yield $99 \%(0.220 \mathrm{~g}, \mathrm{X}=\mathrm{Br}$, method $\mathrm{B}), 99 \%(0.220 \mathrm{~g}, \mathrm{X}=\mathrm{Cl}$, method B). ${ }^{1} \mathrm{H}$ NMR (400 MHz, $\mathrm{CDCl}_{3}$ ): $\delta 2.43$ (s, 3H, Me), 5.85 (br s, $1 \mathrm{H}, \mathrm{NH}), 7.02$ (d, $J=8.5 \mathrm{~Hz}, 2 \mathrm{H}, \mathrm{Ar}), 7.11-7.13(\mathrm{~m}, 2 \mathrm{H}, \mathrm{Ar})$, $7.23(\mathrm{~d}, J=8.1 \mathrm{~Hz}, 2 \mathrm{H}, \mathrm{Ar}), 7.52(\mathrm{~d}, J=8.5 \mathrm{~Hz}, 2 \mathrm{H}, \mathrm{Ar}) .{ }^{13} \mathrm{C} \mathrm{NMR}$ $\left(101 \mathrm{MHz}, \mathrm{CDCl}_{3}\right): \delta 20.9,114.7,121.1(\mathrm{q}, J=33 \mathrm{~Hz}), 121.2,125.0$ $(\mathrm{q}, J=269 \mathrm{~Hz}), 126.8(\mathrm{q}, J=3.8 \mathrm{~Hz}), 130.2,133.1,138.5,147.7$.

3-(Pentafluoro- $\lambda^{6}$-sulfanyl)- $N$-(p-tolyl)aniline (3o). Starting from $0.883 \mathrm{mmol}$ of the corresponding aryl halide, the product was obtained as a white solid: yield $97 \%\left(0.265 \mathrm{~g}\right.$, method B). ${ }^{1} \mathrm{H}$ NMR $\left(400 \mathrm{MHz}, \mathrm{CDCl}_{3}\right): \delta 2.40$ (s, 3H, Me), 5.77 (br s, $\left.1 \mathrm{H}, \mathrm{NH}\right), 7.06-$ 7.13 (m, 3H, Ar), 7.20-7.22 (m, 2H, Ar), 7.25-7.33 (m, 2H, Ar), 7.39-7.40 (m, 1H, Ar). ${ }^{13} \mathrm{C}$ NMR (101 MHz, $\left.\mathrm{CDCl}_{3}\right): \delta 20.9,113.5$ $(\mathrm{p}, J=4.7 \mathrm{~Hz}), 117.0$ (p, $J=4.7 \mathrm{~Hz}), 118.7,120.3,129.5,130.3$, $132.9,138.9,145.0,155.1(\mathrm{p}, J=16.5 \mathrm{~Hz})$. HRMS-EI $(m / z):[\mathrm{M}+$ $\mathrm{H}]^{+}$calcd for $\mathrm{C}_{13} \mathrm{H}_{13} \mathrm{~F}_{5} \mathrm{NS} 310.0683$, found 310.0679 .

$\mathrm{N}$-(p-Tolyl)thiophen-3-amine (3p). Starting from $0.920 \mathrm{mmol}$ of the corresponding aryl halide, the product was obtained as a brown solid: yield $71 \%\left(0.124 \mathrm{~g}\right.$, method B). ${ }^{1} \mathrm{H}$ NMR $\left(400 \mathrm{MHz}, \mathrm{CDCl}_{3}\right)$ : $\delta 2.36(\mathrm{~s}, 3 \mathrm{H}, \mathrm{Me}), 5.66(\mathrm{br} \mathrm{s}, 1 \mathrm{H}, \mathrm{NH}), 6.70(\mathrm{dd}, J=3.1,1.5 \mathrm{~Hz}, 1 \mathrm{H}$, thiophene), 6.92-6.97 ( $\mathrm{m}, 3 \mathrm{H}, \mathrm{Ar} /$ thiophene $), 7.13(\mathrm{~d}, J=8.1 \mathrm{~Hz}$, $2 \mathrm{H}, \mathrm{Ar}), 7.28\left(\mathrm{dd}, J=5.1,3.1 \mathrm{~Hz}, 1 \mathrm{H}\right.$, thiophene). ${ }^{13} \mathrm{C}$ NMR $(101$ $\left.\mathrm{MHz}, \mathrm{CDCl}_{3}\right): \delta 20.7,105.0,116.4,122.6,125.2,129.6,130.0,142.2$, 142.4 .

$N$-(p-Tolyl)benzo[b]thiophen-2-amine (3q). Starting from 0.892 $\mathrm{mmol}$ of the corresponding aryl halide, the product was obtained as a brown solid: yield $49 \%\left(0.104 \mathrm{~g}\right.$, method B). ${ }^{1} \mathrm{H}$ NMR $(400 \mathrm{MHz}$, $\mathrm{CDCl}_{3}$ ): $\delta 2.35$ (s, 3H, Me), $5.91($ br s, $1 \mathrm{H}, \mathrm{NH}), 6.76(\mathrm{~s}, 1 \mathrm{H}, \mathrm{Ar}$ ), 7.04-7.07 (m, 2H, Ar), 7.14 (d, J = 8.1 Hz, 2H, Ar), 7.20-7.25 (m, $1 \mathrm{H}, \mathrm{Ar}), 7.29-7.34$ (m, 1H, Ar), $7.56(\mathrm{~d}, J=7.9 \mathrm{~Hz}, 1 \mathrm{H}, \mathrm{Ar}), 7.67$ (d, $J=8.0 \mathrm{~Hz}, 1 \mathrm{H}, \mathrm{Ar}) .{ }^{13} \mathrm{C} \mathrm{NMR}\left(101 \mathrm{MHz}, \mathrm{CDCl}_{3}\right): \delta 20.8,107.5$, $117.1,121.8,122.0,122.7,124.7,130.1,131.1,134.1,139.9,141.2$, 147.6. HRMS-EI $(m / z):[\mathrm{M}+\mathrm{H}]^{+}$calcd for $\mathrm{C}_{15} \mathrm{H}_{14} \mathrm{NS} 240.0841$, found 240.0841 .

\section{ASSOCIATED CONTENT}

\section{(s) Supporting Information}

The Supporting Information is available free of charge at https://pubs.acs.org/doi/10.1021/acs.organomet.1c00517.

Materials, methods, optimization tables, synthetic procedures, characterization of products, and relevant NMR spectra (PDF)

\section{AUTHOR INFORMATION}

\section{Corresponding Author}

Ashot Gevorgyan - Department of Chemistry, UiT The Arctic University of Norway, 9037 Tromsø, Norway; ๑ orcid.org/ 0000-0002-7968-6695; Email: gevorgyan.ashot@uit.no

\section{Authors}

Kathrin H. Hopmann - Department of Chemistry, UiT The Arctic University of Norway, 9037 Tromsø, Norway; (i) orcid.org/0000-0003-2798-716X

Annette Bayer - Department of Chemistry, UiT The Arctic University of Norway, 9037 Tromsø, Norway; $\odot$ orcid.org/ 0000-0003-3481-200X

Complete contact information is available at:

https://pubs.acs.org/10.1021/acs.organomet.1c00517

\section{Author Contributions}

A.G. directed the project, designed and carried out the experiments, and analyzed the data. A.G. wrote the main manuscript text. K.H.H. and A.B. provided advice to the research and manuscript and granted funding for the research. All authors discussed the results and reviewed the manuscript.

\section{Notes}

The authors declare no competing financial interest.

\section{ACKNOWLEDGMENTS}

This work was performed with support from NordForsk (Grant No. 85378), the Research Council of Norway (Grant No. 313462), and the Tromsø Research Foundation (Grant No. TFS2016KHH). We thank Truls E. Ingebrigtsen for technical support.

\section{REFERENCES}

(1) Ertl, P.; Altmann, E.; McKenna, J. M. The Most Common Functional Groups in Bioactive Molecules and How Their Popularity Has Evolved over Time. J. Med. Chem. 2020, 63, 8408-8418.

(2) For selected reviews on Buchwald-Hartwig amination, see: (a) Surry, D. S.; Buchwald, S. L. Biaryl Phosphane Ligands in Palladium-Catalyzed Amination. Angew. Chem., Int. Ed. 2008, 47, 6338-6361. (b) Ruiz-Castillo, P.; Buchwald, S. L. Applications of Palladium-Catalyzed C-N Cross-Coupling Reactions. Chem. Rev. 2016, 116, 12564-12649. (c) Dorel, R.; Grugel, C. P.; Haydl, A. M. The Buchwald-Hartwig Amination After 25 Years. Angew. Chem., Int. Ed. 2019, 58, 17118-17129.

(3) For selected studies on Buchwald-Hartwig amination, see: (a) Ali, M. H.; Buchwald, S. L. An Improved Method for the Palladium-Catalyzed Amination of Aryl Iodides. J. Org. Chem. 2001, 66, 2560-2565. (b) Kataoka, N.; Shelby, Q.; Stambuli, J. P.; Hartwig, J. F. Air Stable, Sterically Hindered Ferrocenyl Dialkylphosphines for Palladium-Catalyzed C-C, C-N, and C-O Bond-Forming CrossCouplings. J. Org. Chem. 2002, 67, 5553-5566. (c) Hooper, M. W.; Utsunomiya, M.; Hartwig, J. F. Scope and Mechanism of PalladiumCatalyzed Amination of Five-Membered Heterocyclic Halides. J. Org. Chem. 2003, 68, 2861-2873. (d) Huang, X.; Anderson, K. W.; Zim, D.; Jiang, L.; Klapars, A.; Buchwald, S. L. Expanding Pd-Catalyzed C$\mathrm{N}$ Bond-Forming Processes: The First Amidation of Aryl Sulfonates, Aqueous Amination, and Complementarity with $\mathrm{Cu}$-Catalyzed Reactions. J. Am. Chem. Soc. 2003, 125, 6653-6655. (e) Nishio, R.; Wessely, S.; Sugiura, M.; Kobayashi, S. Synthesis of Acridone Derivatives Using Polymer-Supported Palladium and Scandium Catalysts. J. Comb. Chem. 2006, 8, 459-461. (f) Ikawa, T.; Barder, T. E.; Biscoe, M. R.; Buchwald, S. L. Pd-Catalyzed Amidations of Aryl Chlorides Using Monodentate Biaryl Phosphine Ligands: A Kinetic, Computational, and Synthetic Investigation. J. Am. Chem. Soc. 2007, 129, 13001-13007. 
(4) Brown, D. G.; Bostrom, J. Analysis of Past and Present Synthetic Methodologies on Medicinal Chemistry: Where Have All the New Reactions Gone? J. Med. Chem. 2016, 59, 4443-4458.

(5) Schneider, N.; Lowe, D. M.; Sayle, R. A.; Tarselli, M. A.; Landrum, G. A. Big Data from Pharmaceutical Patents: A Computational Analysis of Medicinal Chemists' Bread and Butter. J. Med. Chem. 2016, 59, 4385-4402.

(6) (a) Ghiandoni, G. M.; Bodkin, M. J.; Chen, B.; Hristozov, D.; Wallace, J. E. A.; Webster, J.; Gillet, V. J. Development and Application of a Data-Driven Reaction Classification Model: Comparison of an Electronic Lab Notebook and Medicinal Chemistry Literature. J. Chem. Inf. Model. 2019, 59, 4167-4187. (b) See also: http://nextmovesoftware.com/blog/2013/04/22/pharmas-favouritereactions/, last accessed at 30.06.2021.

(7) For selected studies on the influence of the nature of precatalysts and other parameters on Buchwald-Hartwig amination, see: (a) Carole, W. A.; Bradley, J.; Sarwar, M.; Colacot, T. J. Can Palladium Acetate Lose Its "Saltiness"? Catalytic Activities of the Impurities in Palladium Acetate. Org. Lett. 2015, 17, 5472-5475. (b) Carole, W. A.; Colacot, T. J. Understanding Palladium Acetate from a User Perspective. Chem. - Eur. J. 2016, 22, 7686-7695. (c) Richardson, J.; Ruble, J. C.; Love, E. A.; Berritt, S. A Method for Identifying and Developing Functional Group Tolerant Catalytic Reactions: Application to the Buchwald-Hartwig Amination. J. Org. Chem. 2017, 82, 3741-3750. (d) Weber, P.; Biafora, A.; Doppiu, A.; Bongard, H.-J.; Kelm, H.; Gooßen, L. J. A Comparative Study of Dibenzylideneacetone Palladium Complexes in Catalysis. Org. Process Res. Dev. 2019, 23, 1462-1470. (e) Pentsak, E. O.; Eremin, D. B.; Gordeev, E. G.; Ananikov, V. P. Phantom Reactivity in Organic and Catalytic Reactions as a Consequence of Microscale Destruction and Contamination Trapping Effects of Magnetic Stir Bars. ACS Catal. 2019, 9, 3070-3081.

(8) For our recent study on the application of vegetable oils in chemical synthesis, see: (a) Gevorgyan, A.; Hopmann, K. H.; Bayer, A. Lipids as Versatile Solvents for Chemical Synthesis. Green Chem. 2021, 23, 7219-7227. See also: (b) Noppawan, P.; Sangon, S.; Supanchaiyamat, N.; Hunt, A. J. Vegetable oil as a highly effective $100 \%$ bio-based alternative solvent for the one-pot multicomponent Biginelli reaction. Green Chem. 2021, 23, 5766-5774. (c) Ishizuka, F.; Stenzel, M. H.; Zetterlund, P. B. Microcapsule Synthesis via RAFT Photopolymerization in Vegetable Oil as a Green Solvent. J. Polym. Sci., Part A: Polym. Chem. 2018, 56, 831-839.

(9) For selected studies on sustainable amination reactions, see: (a) Wagner, P.; Bollenbach, M.; Doebelin, C.; Bihel, F.; Bourguignon, J.-J.; Salome, C.; Schmitt, M. $t$-BuXPhos: a highly efficient ligand for Buchwald-Hartwig coupling in water. Green Chem. 2014, 16, 41704178. (b) Sa, S.; Gawande, M. B.; Velhinho, A.; Veiga, J. P.; Bundaleski, N.; Trigueiro, J.; Tolstogouzov, A.; Teodoro, O. M. N. D.; Zboril, R.; Varma, R. S.; Branco, P. S. Magnetically recyclable magnetite-palladium (Nanocat-Fe-Pd) nanocatalyst for the Buchwald-Hartwig reaction. Green Chem. 2014, 16, 3494-3500. (c) Petkova, D.; Borlinghaus, N.; Sharma, S.; Kaschel, J.; Lindner, T.; Klee, J.; Jolit, A.; Haller, V.; Heitz, S.; Britze, K.; Dietrich, J.; Braje, W. M.; Handa, S. Hydrophobic Pockets of HPMC Enable Extremely Short Reaction Times in Water. ACS Sustainable Chem. Eng. 2020, 8, 12612-12617. (d) Srivastava, A. K.; Sharma, C.; Joshi, R. K. $\mathrm{Cp} * \mathrm{Co}(\mathrm{III})$ and $\mathrm{Cu}(\mathrm{OAc})_{2}$ bimetallic catalysis for Buchwald-type C$\mathrm{N}$ cross coupling of aryl chlorides and amines under base, inert gas \& solvent-free conditions. Green Chem. 2020, 22, 8248-8253. (e) Kubota, K.; Takahashi, R.; Uesugi, M.; Ito, H. A Glove-Boxand Schlenk-Line-Free Protocol for Solid-State C-N Cross-Coupling Reactions Using Mechanochemistry. ACS Sustainable Chem. Eng. 2020, 8, 16577-16582.

(10) Triacetin and tributyrin are present in small quantities in vegetable oils and butter.

(11) For an overview of natural amphiphiles, see: Foley, P.; Kermanshahi pour, A.; Beach, E. S.; Zimmerman, J. B. Derivation and synthesis of renewable surfactants. Chem. Soc. Rev. 2012, 41, 14991518 .
(12) For selected reviews on reversed micelles, see: (a) Melo, E. E.; Aires-Barros, M. R.; Cabral, J. M. S. Reverse micelles and protein biotechnology. Biotechnol. Annu. Rev. 2001, 7, 87-129. (b) Ganguli, A. K.; Ganguly, A.; Vaidya, S. Microemulsion-based synthesis of nanocrystalline materials. Chem. Soc. Rev. 2010, 39, 474-485. (c) Correa, N. M.; Silber, J. J.; Riter, R. E.; Levinger, N. E. Nonaqueous Polar Solvents in Reverse Micelle Systems. Chem. Rev. 2012, 112, 4569-4602. (d) Das, A.; Yadav, N.; Manchala, S.; Bungla, M.; Ganguli, A. K. Mechanistic Investigations of Growth of Anisotropic Nanostructures in Reverse Micelles. ACS Omega 2021, 6, 1007-1029.

(13) For selected reviews on reactions enabled by micelles, see: (a) Zhao, Y. Surface-Cross-Linked Micelles as Multifunctionalized Organic Nanoparticles for Controlled Release, Light Harvesting, and Catalysis. Langmuir 2016, 32, 5703-5713. (b) Lipshutz, B. H. When Does Organic Chemistry Follow Nature's Lead and "Make the Switch”? J. Org. Chem. 2017, 82, 2806-2816. (c) Lipshutz, B. H.; Ghorai, S.; Cortes-Clerget, M. The Hydrophobic Effect Applied to Organic Synthesis: Recent Synthetic Chemistry "in Water. Chem. Eur. J. 2018, 24, 6672-6695. (d) Serrano-Luginbuhl, S.; Ruiz-Mirazo, K.; Ostaszewski, R.; Gallou, F.; Walde, P. Soft and dispersed interfacerich aqueous systems that promote and guide chemical reactions. Nat. Rev. Chem. 2018, 2, 306-327. (e) Cortes-Clerget, M.; Yu, J.; Kincaid, J. R. A.; Walde, P.; Gallou, F.; Lipshutz, B. H. Water as the reaction medium in organic chemistry: from our worst enemy to our best friend. Chem. Sci. 2021, 12, 4237-4266. 